\title{
Demographic Influences towards Online Classes: A Correlational Analysis
}

\author{
Kingie G. Micabalo ${ }^{1}$, Jesszon B. Cano ${ }^{2}$, June Ace P. Navarro ${ }^{3}$, \\ Arsenio Robert N. Tan ${ }^{4}$ and Ryan D. Montilla ${ }^{5}$ \\ ${ }_{1,3,4 \& 5}$ Business and Accountancy, University of Cebu-Cebu City, Philippines \\ ${ }^{2}$ Hospitality Management, Bohol Island State University, Candijay, Philippines \\ E-mail:kmicabalo@uc.edu.ph, jesszon.cano@bisu.edu.ph, janavarro@uc.edu.ph, artan@uc.edu.ph,rmontilla@uc.edu.ph
}

\begin{abstract}
An online teacher needs to give a constant flow of commitment that can serve the progression of unessential data that goes after both time and core interest. The study determines the correlation of demographic profile and its influences on student's perception towards online classes. The study contrived 313 respondents who are currently enrolled in the College using the snowball inspecting strategy. Frequency and simple percentage, Weighted Mean, Chi-Square Test of Independence, and one-way ANOVA were used to analyzed and interpret the data accumulated. The discoveries uncovered that the understudies slightly perceived online classes in learning diversification, peer interactions, user-friendliness, online course quality, and course design. The investigation also revealed a statistically significant relationship between the respondent's course, family income, and family structure to the level of perception towards online classes. Moreover, there is a statistically significant difference between family income and family structure by its influence on students' perception of online classes. The study concluded that correlational analysis among students explains the demographic factors affecting their concentration on online classes. Family income and structure play a significant role and greatly influences understudies enthusiasm in the College of Business and Accountancy online classes.
\end{abstract}

Keywords: Business and Accountancy, Online Teaching, Descriptive Correlational, Mandaue City, Philippines

\section{INTRODUCTION}

Innovation empowers understudies to associate the educator and the substance. Notwithstanding, interruptions as constant electronic discussions and a torrent of many businesses and individual additions can be inescapable. Maybe the online teacher needs to give a constant flow of commitment that can intrude (in any event incidentally) the progression of superfluous data that seeks both time and core interest (Dail, 2010).

The global pandemic has affected almost, if not all, industries all over the world. Here in the Philippines, Filipinos are badly hit by the ripple effects of the COVID19 that affected every aspect of their lives: their jobs, health, well-being, and, yes, their education. The early ending of the school year (a precaution to prevent the further spread of the virus) is a clear sign of how the current school system can be affected by a global pandemic. With the danger of COVID-19 still on the ascent, with no away from of how (and when) it will end, the Department of Education
(DepEd) saw itself confronted with a significant and critical task: to keep up the progression of value training in the Philippines while protecting its partners' wellbeing simultaneously. Though health precautions are, without a doubt, a paramount consideration in these challenging times, Filipinos' education cannot be left behind, even during this crisis.

In the Philippines, the expression "e-learning" is utilized interchangeably with internet learning and concerns the online conveyance of instructional substance just as related support services to under studies. It is essentially founded on encounters at the University of the Philippines Open University (UPOU). It features the improvement of elearning in the nation from simply an enhancement inside once-a-month face-to-face (FTF) sessions in a university learning center to more extensive use of a learning management system (LMS) as a setting for scholastic conversations just as learning appraisals, sharing learning assets and substance, and understudies entries necessities. A cell phone is being utilized to connect the advanced separation and cause the carefully prohibited areas of the Filipino society to turn out to be essential for the internet learning project of the College. Moreover, the systems being utilized to guarantee quality schooling in e-learning just as the difficulties looked by e-learning organizations are broadly unavoidable (Dela Pena, 2009).

With this severe problem, the Department of Education decided that it is time for the Philippines to adopt distance learning fully. This activity would use the intensity of current innovations to furnish instruction even with critical restrictions, for example, network isolates and social separating approaches. DepEd's online learning platform is specially crafted to deal with the current limitations that both teachers and students face during the crisis. Their platform is a convenient place where interactive and remote activities can be performed. It also supports the fast distribution of educational resources to teachers and students no matter where they are. All these things are possible because the platform taps the current and proven technologies that provide practical solutions to the education sector's problems right now. Without a doubt, this initiative from the Department of Education is laudable. However, the DepEd (including us) are still faced with 
another hurdle that will surely limit the full realization of distance learning in the Philippines. The Department of Education (DepEd) cannot deny that most public school students cannot afford the necessary equipment for their distance learning initiative (Llego, 2020).

There is a gap in particular for the College of Business and Accountancy department students who struggle in transitioning from the face-to-face modality of teaching to online classes. As the understudies mentioned above are facing, the department also struggles to realign certain techniques and methodologies to reach out among students' concerns and realize higher enrolment rates. By the presented situation, the faculty members of the department handling business management and economics subjects and faculty researchers intend to propose practical measures towards teaching and learning alignment on online classes. Hence, this study is undertaken to assist faculty members in enhancing teaching and learning techniques suited to the students' expectations and status on the $1^{\text {st }}$ semester S.Y. 2020-2021, despite the country's situation with the covid-19 pandemic. This investigation is also conducted to further enhance the faculty members' existing efforts to reach out to students' queries and problems regarding online classes.

\section{FRAMEWORK}

This study is anchored on Connectivism Theory, a moderately new learning hypothesis created and dependent on the possibility that individuals cycle data by framing associations. This hypothesis has created with the computerized and innovation age, adjusting to progress in these fields. This new hypothesis proposes that individuals presently do not quit learning after proper training and keep on picking up information from different roads, for example, work abilities, systems administration, experience, and admittance to data with new instruments in innovation (Siemens, 2005).Connectivism is a learning theory that explains how Internet advancements have made new open entryways for people to learn and share information across the World Wide Web. These headways consolidate Web programs, email, wikis, online discussion social events, relational associations, YouTube, and different instruments that engage them to learn and grant information to other people.

A basic component of connectivism is that much learning can happen across peer networks on the web. In connectivist learning, a teacher will oversee understudies to information and answer basic requests differing, to help understudies learning and sharing. Understudies are additionally asked to look out information freely on the web and express what they find. A related organization around this shared information often results. The massive open online course (MOOC) marvel comes from the connectivist hypothesis. In a connectivist MOOC (c MOOC), it is available to any individual who needs to enlist. It utilizes open programming and frameworks across the Web to encourage learning and sharing. It happens fundamentally on the web. It occurs as indicated by a predefined educational plan for an assigned timeframe. While facilitators manage the c MOOC, its members are to a great extent liable for what they realize and what and how they share it; this associated conduct generally makes the course content (Downes, 2010).

Systems Theory of Mead (2019) further backs the examination. It is an interdisciplinary investigation of frameworks with a firm combination of interrelated and related parts that are either normal or human-made. Every framework is portrayed by its spatial and worldly limits, encircled and affected by its current circumstance, depicted by its structure and reason or nature, and communicated in its working. A framework can be more than the number of its parts if it communicates collective energy or rising conduct regarding its belongings. Transforming one piece of the framework as a rule influences different parts and the entire framework, with unsurprising examples of behavior. For self-learning and self-adjusting frameworks, the positive development and transformation rely on how well the framework is changed with its environment.

Some frameworks work primarily to help different frameworks by supporting the other framework's upkeep to forestall failure. The objective of systems theory is methodically finding a system's dynamics, limitations, conditions and explaining standards (reason, measure, techniques, and instruments) that can be recognized and applied to frameworks at each degree of settling each field for accomplishing improved equifinality. Frameworks change has arisen as a prevailing casing through which nearby, state and public funders and specialists across a wide exhibit of fields approach an individual's work.

In the greater part of these endeavors, change specialists and researchers endeavor to move human administrations and network frameworks to make better and all the more results and improve the business as usual. Despite this, there is a lack of structures that researchers, experts, and funders can attract to help them in agreement, planning, and surveying this cycle from a fundamental point of view.

The proposed investigation of Foster features the significance of taking care of both the profound and evident structures inside a framework, just as the collaborations and interdependencies among these framework parts. It incorporates taking care of the predominant standardizing, asset, regulative, and operational attributes that direct the conduct and encounters of framework individuals (Foster $e t$ al., 2007).

Moreover, frameworks have upgraded the exhibition of both the educators and the understudies. Using innovation, the school, the board, and the educators can get information that can be utilized to give guides on the best way to improve the exhibition of the understudies. The understudy Intern organizer can do an appraisal, and the understudy conduct to recognize the zones where the understudy is feeble, which needs upgrade and advancement. By that, educators 
can adjust the advancement plan appropriately to improve understudy execution as assistants (Miller, 2017).

Program Theory further backings the investigation, which gives a lucid image of how change happens and how to improve execution. The Program Theory tells the best way to create, speak to, and use program hypothesis nicely and deliberately to suit a specific circumstance. The necessities appraisal to mediation plan, from usage to results assessment, from strategy detailing to strategy execution and assessment, program hypothesis is vital (Funnell, and Rogers, 2011).

Program hypothesis is a bunch of express or certain suspicions by partners about what activity is needed to address a social, instructive, or medical condition and why the difficult will react to this activity (Chen, 2012). Program Theory is not just to survey whether mediation works or does not work, but also how and why it does. The data is basic for partners to improve their current or future projects (Chen, 2012).

Program hypothesis is a deliberate arrangement of partners' prescriptive presumptions and spellbinding suspicions hidden projects, regardless of whether express or certain. Spellbinding presumptions, called the change model, manage what causal cycles are relied upon to achieve program objectives. Prescriptive suspicions, called the activity model, manage what moves should be made in a program to create alluring changes. Program hypothesis utilizes the activity model and change model to address relevant factors and arranging, and execution gives that are enormously intrigued to partners (Donaldson, 2012).

\section{OBJECTIVES OF THE STUDY}

The examination plans to decide the connection between the understudy's demographic profileand the level of understudy's discernment towards online classes. The consequence of this examination filled in as the reason for the detailing of an intercession intends to increase online classes' importance to the understudies' current and future requirements. Specifically, it identifies the respondent's profile in terms of age, gender, course, year level, family income, family status, and online mechanisms. It seeks to identify students' perception of online classes in terms of learning diversification, peer interactions, user-friendliness, and online course quality and course design.

\section{METHODOLOGY}

\section{A. Research Design}

The investigation utilized a descriptive-correlational research method with the questionnaire as the principal tool in data gathering to determine the correlation between the student's demographic profile and the degree of student's perception towards online classes.

\section{B. Research Site}

The investigation was driven at the University of Cebu Lapu-Lapu, and Mandaue grounds settled at A.C. Cortes Ave., Mandaue City. It offers Accountancy, Business Administration with four majors: Management Accounting, Marketing Management, Financial Management, and Human Resource Development Management. Since the examination was to distinguish the students' perception of online and traditional classes, the zone was useful for the investigation.

\section{Respondents}

The investigation study contrived 313 respondents who are currently enrolled from the College of Business and Accountancy. Slovin's formula was used to decide the examination's sample size on a snowball inspecting strategy.

\section{Instrumentation}

The examination uses a self-assembled study survey made out of two sections. The underlying portion is the respondent's demographic profile regarding age, gender, course, year level, family income, family status, and online mechanisms. The next part is students' perception of an online class in learning diversification, peer interactions, user-friendliness, and online course quality and course design. A parameter for interpretation was used: (1) Not Perceived, (2) Slightly Perceived, (3) Moderately Perceived, (4) Highly Perceived.

\section{E. Treatment of Data}

Frequency and simple percentage, Weighted Mean, and Chi-Square Test of Independence, One way ANOVA was used to analyzed and interpret the data accumulated.

\section{F. Research Procedure}

\section{Data Gathering}

To achieve the examination study, a Letter of aim routed to the Dean of College of Business and Accountancy with the end goal of information gathering, requesting that authorization lead the review and get the all-out number of enlisted understudies. The polls were directed to the exceptional year levels through Google structure survey as the primary instrument on a snowball examining strategy.

\section{RESULTS AND DISCUSSION}

This section presents the after effects of the information gathered. The first part presents the respondents' profile, while the next part presents the information fair and square of understudy's insight towards online classes in the College of Business and Accountancy. 
TABLE I PROFILE OF THE RESPONDENTS (N=313)

\begin{tabular}{|c|c|c|}
\hline & Frequency & Percentage \\
\hline \multicolumn{3}{|l|}{ Age } \\
\hline 18-19 & 92 & 29.40 \\
\hline $20-21$ & 176 & 56.20 \\
\hline $22-23$ & 21 & 6.70 \\
\hline $24-25$ & 9 & 2.90 \\
\hline \multirow[t]{2}{*}{ 26-up } & 15 & 4.80 \\
\hline & & 100.00 \\
\hline \multicolumn{3}{|c|}{ Gender } \\
\hline Male & 48 & 15.30 \\
\hline \multirow[t]{2}{*}{ Female } & 265 & 84.70 \\
\hline & & 100.00 \\
\hline \multicolumn{3}{|c|}{ Course } \\
\hline BSA & 66 & 21.10 \\
\hline MA & 59 & 18.80 \\
\hline FM & 71 & 22.70 \\
\hline MM & 77 & 24.60 \\
\hline \multirow[t]{2}{*}{ HRDM } & 40 & 12.80 \\
\hline & & 100.00 \\
\hline \multicolumn{3}{|c|}{ Year Level } \\
\hline 1st year & 149 & 47.60 \\
\hline 2nd year & 119 & 38.00 \\
\hline 3rd year & 31 & 9.90 \\
\hline \multirow[t]{2}{*}{4 th year } & 14 & 4.50 \\
\hline & & 100.00 \\
\hline \multicolumn{3}{|c|}{ Family Income } \\
\hline Less than Php 10, 000.00 & 256 & 81.80 \\
\hline Php 10, 001.00 to Php 20,000.00 & 34 & 10.90 \\
\hline Php 20, 001.00 to Php 30, 000.00 & 10 & 3.20 \\
\hline \multirow[t]{2}{*}{ Php 30, 000.01 and up } & 13 & 4.20 \\
\hline & & 100.00 \\
\hline \multicolumn{3}{|c|}{ Family Structure } \\
\hline Traditional Family & 244 & 78.00 \\
\hline Single Parent Family & 53 & 16.90 \\
\hline Step Family & 6 & 1.90 \\
\hline \multirow[t]{2}{*}{ Grand Parent Family } & 10 & 3.20 \\
\hline & & 100.00 \\
\hline \multicolumn{3}{|c|}{ Available Online Mechanism } \\
\hline Cell phone (Smartphone/Android) & 154 & 49.20 \\
\hline Laptop/Netbook & 158 & 50.50 \\
\hline \multirow[t]{2}{*}{ Tablet } & 1 & 0.30 \\
\hline & & 100.00 \\
\hline \multicolumn{3}{|c|}{ Available Internet Connection } \\
\hline Prepaid load (Data connection) & 155 & 49.50 \\
\hline $\begin{array}{l}\text { Wireless Fidelity (wi-fi } \\
\text { connection) }\end{array}$ & 158 & 50.50 \\
\hline
\end{tabular}

Table I shows the respondents' segment profile. It shows that the greater parts of the respondents are at the age of 2021 , reciprocals to 56.20 percent. This information infers that the understudies in CBA are at the youthful grown-up's stage. They were upheld by the Education State University (2019), expressing that the Philippines' Higher training is firmly in the private area. Most four-year college educations are for a very long time. Understudies are generally from 17 to 21 years of age. As to gender, 84.70 percent were females. It entails that females are more inclined to go to College than males. Across socioeconomic classes, women are increasingly enrolling and completing postsecondary education, while, even as opportunities for people without a college education shrink, men's graduation rates remain relatively stagnant (Semuels, 2017). As to course majors, 24.60 percent were marketing majors. It entails that most of the understudies decide to enroll in the marketing program. As per Siu (2017), a degree in marketing is a keen thought accomplishment in promoting a four-year college education in a few fields. However, a marketing degree makes it simpler to find a passage level work and ascend in the area quicker. As to year level, 47.60 percent were on the $1^{\text {st }}$ year. It infers that in the acclimation of online classes, most enrollees are on the 1st year level.

Concerning family pay, 81.80 percent of the respondents were having a pay of under P10,000.00. According to the Philippines Statistics Authority (2019), the income gap between the most extravagant decile and the least fortunate decile stays wide. By and large. The families in the most unfortunate decile then procured a normal yearly pay of 69 thousand pesos or around 6 thousand pesos month to month. The families' pay in the most extravagant decile is multiple times that of the least fortunate decile. As to family structure, 78percent of the respondents have aplace with a conventional family. It entails that the respondents put family ties and relations as one of their top priorities. Filipinos would do all they could to provide and sustain their respective families. The jobs of moms and fathers are delineated along customary sex lines, such as mentalities and practices towards kids, the idea of parent-youngster connections, and the separated parts of moms and fathers, and children's daughters (Alampay, 2014). Regarding the accessibility of online systems and web associations, most respondents have a PC and cell phones utilizing wifi and portable information associations.

Table II shows the Level of Student's Perception towards Online Classes in the following aspects; learning diversification, peer interactions, user-friendliness, online course quality, and course design. The indicator in which students understand the importance of the topic discussed through virtual discussion recorded the highest mean of 2.17 and interpreted as slightly perceived as to learning diversification. It suggests that the understudies were most certainly not fascinated by perceiving diversified learning through online classes. Then again, a marker is expanded learning through examination thought by riding the web and understanding diaries or articles recorded. The respondents slightly perceived the least mean of 1.96. It implies that respondents do not use the online platform to widen their perspective by reading different literature sources. It was 
reinforced by Wragg et al. (2019), stating that differentiated encouraging systems in college courses and assessment of the commitment of these methodologies and their setting of utilization on understudy learning inspiration factors balance the advantages of methodology broadening on understudies' inspiration to learn.

TABLE II LEVEL OF STUDENT'S PERCEPTION OF ONLINE CLASSES

\begin{tabular}{|c|c|c|c|}
\hline & Mean & Interpretation & Rank \\
\hline \multicolumn{4}{|l|}{ Learning Diversification } \\
\hline $\begin{array}{l}\text { The student understands the importance of the topic that is being discussed } \\
\text { through virtual discussion. }\end{array}$ & 2.17 & Slightly Perceived & 1 \\
\hline $\begin{array}{l}\text { The student conceptualizes all the inputs coming from the online discussion and } \\
\text { applies it to personal lives. }\end{array}$ & 2.16 & Slightly Perceived & 2 \\
\hline $\begin{array}{l}\text { The student learns the basic principles, theories, and concepts of the subject that } \\
\text { he/she will enroll with online applications software. }\end{array}$ & 2.14 & Slightly Perceived & 3 \\
\hline The student acquires technical skills with regards to technology utilization. & 1.98 & Slightly Perceived & 4 \\
\hline $\begin{array}{l}\text { Increased learning through research ideas by surfing the internet and by reading } \\
\text { journals or articles. }\end{array}$ & 1.96 & Slightly Perceived & 5 \\
\hline Aggregate Mean & 2.08 & Slightly Perceived & \\
\hline \multicolumn{4}{|l|}{ Peer Interactions } \\
\hline $\begin{array}{l}\text { Increases student engagement during grouping sessionsby the use of social } \\
\text { mediaplatforms. }\end{array}$ & 2.34 & Slightly Perceived & 1 \\
\hline $\begin{array}{l}\text { Teachers' assessment and evaluation of students' performance increases through a } \\
\text { virtual connection. }\end{array}$ & 2.30 & Slightly Perceived & 2 \\
\hline $\begin{array}{l}\text { The students easily directed queries and clarification towards the person being } \\
\text { asked. }\end{array}$ & 2.27 & Slightly Perceived & 3 \\
\hline $\begin{array}{l}\text { The student-teacher interaction during class discussions intensifies through the use } \\
\text { of online application software. }\end{array}$ & 2.20 & Slightly Perceived & 4 \\
\hline $\begin{array}{l}\text { Exchange of knowledge and ideas among students increases through the } \\
\text { adaptation of social media during class discussions. }\end{array}$ & 2.11 & Slightly Perceived & 5 \\
\hline Aggregate Mean & 2.24 & Slightly Perceived & \\
\hline \multicolumn{4}{|l|}{ User-friendliness } \\
\hline $\begin{array}{l}\text { The online enrolment process is understandable with the use of online application } \\
\text { software. }\end{array}$ & 2.22 & Slightly Perceived & 1 \\
\hline The website/ department portals/ Facebook page is available for queries. & 2.21 & Slightly Perceived & 1 \\
\hline $\begin{array}{l}\text { The organized portal enables the students to easily determine the subjects that } \\
\text { he/she needs to enroll. }\end{array}$ & 2.05 & Slightly Perceived & 2 \\
\hline The difficulty of system usage in the online class. & 1.94 & Slightly Perceived & 3 \\
\hline $\begin{array}{l}\text { The student pays his/her entrance fee conveniently through affiliated banks and } \\
\text { other remittances. }\end{array}$ & 1.87 & Slightly Perceived & 4 \\
\hline Aggregate Mean & 2.06 & Slightly Perceived & \\
\hline \multicolumn{4}{|l|}{ Online Course Quality } \\
\hline The online course is full of learning with the aid of technology. & 2.25 & Slightly Perceived & 1 \\
\hline The students were able to conceptualize and integrate the topics being discussed. & 2.23 & Slightly Perceived & 2 \\
\hline $\begin{array}{l}\text { It encourages students to read more about the topics being discussed to enhance } \\
\text { their knowledge and ideas further. }\end{array}$ & 2.16 & Slightly Perceived & 3 \\
\hline The online course has e-books and other available reference materials. & 2.16 & Slightly Perceived & 4 \\
\hline $\begin{array}{l}\text { The teacher exhibits expertise and capabilities in handling online classeswith the } \\
\text { use of the applicationsoftware. }\end{array}$ & 2.10 & Slightly Perceived & 5 \\
\hline Aggregate Mean & 2.18 & Slightly Perceived & \\
\hline \multicolumn{4}{|l|}{ Course Design } \\
\hline $\begin{array}{l}\text { Video recording of the class discussions is available in Google classroom for } \\
\text { students to review. }\end{array}$ & 2.25 & Slightly Perceived & 1 \\
\hline $\begin{array}{l}\text { Both asynchronous and synchronousdelivery of teaching and learning isadopted to } \\
\text { predict higher performance rating among students. }\end{array}$ & 2.14 & Slightly Perceived & 2 \\
\hline Online examinations and evaluations are comprehensive and understandable. & 2.11 & Slightly Perceived & 3 \\
\hline $\begin{array}{l}\text { Student engagement rules and policies with the virtual topic discussion provide a } \\
\text { venue for learning. }\end{array}$ & 2.02 & Slightly Perceived & 4 \\
\hline $\begin{array}{l}\text { Immediate social media platforms were usedto increase studentconvenience in } \\
\text { online classes. }\end{array}$ & 1.99 & Slightly Perceived & 5 \\
\hline Aggregate Mean & 2.10 & Slightly Perceived & \\
\hline
\end{tabular}


As to Peer Interactions, the indicator to increase student engagement during grouping sessions by using social media platforms recorded the highest mean of 2.34 and interpreted as slightly perceived by the respondents. It means that the online platform did not statistically increase the group engagement of the respondents. On the other hand, an indicator that is an exchange of knowledge and ideas among students increases through social media adaptation during class discussion recorded the lowest mean of 2.11 and interpreted as slightly perceived. It implies that the exchange of ideas through social media is not that perceived by the respondents. Juvonen et al., (2012) stated that companions and other friend connections could inspire understudies to participate in school the same as in extracurricular exercises. Seeing how companions matter, research on the positive and negative engagement "effects" of companions, and socially minimizing encounters, for example, peer dismissal and harassing, is exceptionally significant.

As to user-friendliness, the indicator, which is the online enrolment process, is understandable with the use of online application software recorded the highest mean of 2.22 and recorded as slightly perceived. It means that respondents did not perceive an organized enrolment process throughout online classes. On the other hand, an indicator which is the student pays his/her entrance fee conveniently through affiliated banks and other remittances recorded the lowest mean at 1.87 and interpreted as slightly perceived. It means that students encountered difficulties in paying their school fees in banks and other remittances. The mark of a great online training course is not just about the content. Since such courses depend on sight and sound, interconnected insight to prepare and teach learners, all aspects of the course's design, from images and text to overall site functionality, must work in harmony to meet and exceed the expectations of the course's user base (Lynch, 2019).

As to online course quality, an indicator in which the online course is full of learning with the aid of technology recorded the highest mean at 2.25 and interpreted as slightly perceived by the respondents. It means that online learning through the aid of technology was not that perceived by the students. On the other hand, an indicator in which the teacher exhibits expertise and capabilities in handling online class using the application software recorded the lowest mean of 2.10 and interpreted as slightly perceived. It implies that students did not see the expertise of the teachers handling online classes. Course quality standards are a valuable component in the instructional design process.

They help guide course writers and identify needed improvements within courses and programs, and they create consistency in both faculty expectations and the student experience. Also, course quality standards allow institutions to identify and select standards that best reflect their brand, mission, and values in online education (Crews et al., 2017).
Further, quality is becoming front and center as online distance education moves into the mainstream of higher education (Chao et al., 2010).

As to course design, the indicator, which is the video recording of the class discussions, is available in Google classroom for students to review recorded the highest mean of 2.25 and interpreted as slightly perceived. It implies that although instructions were given already by the institution about the synchronous and asynchronous modality of teaching, the students did not highly perceive its execution among teachers. The indicator in which immediate social media platforms were used to increase student convenience on online classes recorded the lowest mean of 1.99 and interpreted as slightly perceived by the students. It means that social media were not evident usage among teachers to maximize student convenience in online classes. Successful courses require careful planning and continual revision. Consult with colleagues who have taught the same or similar courses to learn from their strategies and their general impressions of the students who typically take the course (Parrish, 2020). All professors would like their students to be prepared when they come to class, be motivated to learn, and achieve high-quality learning that prepares them for future classes and future personal, social, and professional life experiences (Dee, 2017.)

In general, learning diversification, peer interactions, userfriendliness, online course quality, and course design were slightly perceived by the student respondents. It implies that all areas needed for online classes to be efficient and effective lack of a motivating factor, guiding policy and instruments to fill in the gaps between students' teaching and learning. Furthermore, the students' perception clearly defines a gap that needs to be aligned to promote resiliency in any situations that may arise, confronting the College of Business and Accountancy program outcomes.

Table III shows the Significant Relationship between the Respondents' Profile and the level of student's perception towards Online Classes. The data revealed that there is a statistically significant relationship between the respondent's course, family income, and family structure ( $\mathrm{p}$-value <.05) to the level of perception towards online classes. It means that this demographic profiling directly affects the level of student's perception of online classes.

This is further supported by According to Nikitina (2019), stating that there's a pervasive link between socioeconomic status and academic achievement, with poor students often getting the shorter end of the stick. Socioeconomic status affects academic achievement; that is, poor students, get just as poor test scores. Despite these limiting factors, it's the educators' and education regulators' jobs to ensure that students, rich or poor, continue to learn their lessons effectively. 
TABLE III SIGNIFICANTRELATIONSHIP BETWEEN THE RESPONDENTS PROFILE AND THE LEVEL OF STUDENTS PERCEPTION TOWARDS ONLINE CLASSES $(\propto=0.05)$

\begin{tabular}{|l|c|c|c|c|c|}
\hline \multicolumn{1}{|c|}{ Variables } & Computed Chi-Square & df & Critical Value & Significance & Result \\
\hline Age & $234.714^{\mathrm{a}}$ & 240 & 277.138 & Not Significant & Accept Ho \\
\hline Gender & $60.246^{\mathrm{a}}$ & 60 & 79.082 & Not Significant & Accept Ho \\
\hline Course & $264.043^{\mathrm{a}}$ & 240 & 277.138 & Significant & Reject Ho \\
\hline Year Level & $196.115^{\mathrm{a}}$ & 180 & 212.304 & Not Significant & Accept Ho \\
\hline Family Income & $226.873^{\mathrm{a}}$ & 180 & 212.304 & Significant & Reject Ho \\
\hline Family Structure & $216.494^{\mathrm{a}}$ & 180 & 212.304 & Significant & Reject Ho \\
\hline Online Mechanism & $86.172^{\mathrm{a}}$ & 120 & 146.567 & Not Significant & Accept Ho \\
\hline Online Connectivity & $81.787^{\mathrm{a}}$ & 120 & 146.567 & Not Significant & Accept Ho \\
\hline
\end{tabular}

Moreover, education theorists have attributed this achievement gap to a cultural mismatch between students and their teachers and schools. At the same time, instructional communication research has found that cultural differences may influence student perceptions of
Teacher communication behaviors and that these behaviors have an effect on learning outcomes. Interestingly, it suggests that family income may influence students' perceptions of their instructor's communication behaviors (Crecelius, 2014).

TABLE IV SIGNIFICANT DIFFERENCEIN THE PROFILE OF THE RESPONDENTS BY ITS INFLUENCE ON THE LEVEL OF STUDENTS PERCEPTION TOWARDS ONLINE CLASSES (DF $=60 ; \propto=0.05$ )

\begin{tabular}{|l|c|c|c|c|}
\hline \multicolumn{1}{|c|}{ Variables } & F-value & P-value & Significance & Result \\
\hline Age & 0.821 & 0.819 & Not Significant & Accept Ho \\
\hline Gender & 1.001 & 0.481 & Not Significant & Accept Ho \\
\hline Course & 1.267 & 0.109 & Not Significant & Accept Ho \\
\hline Year Level & 1.065 & 0.362 & Not Significant & Accept Ho \\
\hline Family Income & 1.358 & 0.050 & Significant & Reject Ho \\
\hline Family Structure & 1.437 & 0.030 & Significant & Reject Ho \\
\hline Online Mechanism & 1.164 & 0.211 & Not Significant & Accept Ho \\
\hline Online Connectivity & 1.073 & 0.347 & Not Significant & Accept Ho \\
\hline
\end{tabular}

Table IV shows the Significant Difference in the respondents' profile by its influences on the level of student's perception towards online classes. The data revealed a statistically significant difference in family income and family structure (p-value <.05) as to its influences on the level of student's perception towards online classes. It implies that family income and family structure indicators have different contributions to students' perception of online classes. However, further research is recommended to establish a greater understanding of these phenomena. Han et al. (2003) further reinforced the above statement, demonstrating that higher family pay is reliably connected with higher school participation rates and spending on education. Kids in single-parent families have lowers school participation rates than youngsters in twoparent families. Besides, single-parent families save on schooling. When family pay is considered, single-parent families are fundamentally not the same as two-parent families on the result factors. Single-parent families, nonetheless, are assessed to have lower school participation rates and informational use in the wake of controlling for family pay altogether.

\section{CONCLUSION}

Innovation empowers understudies to associate the teacher and the substance. In any case, interruptions as continuous electronic discussions and a flood of many business and individual interpositions can be inescapable. The study reveals that online classes categorized in terms of learning diversification, peer interactions, user-friendliness, online course quality, and course design were slightly perceived. However, it was discovered that there is a statistically significant relationship between the respondent's course, family income, and family structure ( $\mathrm{p}$-value <.05) to the level of perception towards online classes. Furthermore, the study revealed a statistically significant difference between family income and family structure (p-value <.05) by influencing students' perception of online classes. The study concluded that correlational analysis among students explains the demographic factors affecting their concentration on online classes. Family income and structure play a vital role and greatly influences their enthusiasm in the College of Business and Accountancy online classes. 


\section{REFERENCES}

[1] Alampay L.P. (2014). Parenting in the Philippines. In: Selin H. (eds) Parenting Across Cultures.Science Across Cultures: The History of Non-Western Science, 7, Springer, Dordrecht. Retrieved from https://bit.ly/3h7aVVX

[2] Chao, I. T., Saj, T., \& Hamilton, D. (2010). Using collaborative course development to achieve online course quality standards.The International Review of Research in Open and Distributed Learning,11(3),1-106. Retrieved from https://bit.ly/37ZzFen

[3] Chen, H. T. (2012). Theory-driven evaluation: Conceptual framework, application, and advancement. Alabama, Birmingham, Sage Publications. ISBN- 1452252440. Retrieved from https://bit.ly/37XIpBT

[4] Crecelius, S. A. (2014). The Effect of Socioeconomic Status on Student Perceptions of Instructional Communication Behaviors. Sycamore Scholars. Retrieved from https://bit.ly/2JbAHM9

[5] Crews, T. B., Bordonada, T. M., \& Wilkinson, K. (2017). Student Feedback on Quality Matters Standards for Online Course Design. Educause review. Retrieved from https://bit.ly/2XFMciO

[6] Dail, T. K. (2010). Online student engagement tools and strategies.Magna Publications Inc. Retrieved on August 6, 2020. Retrieved from https://bit.ly/2PtW6zF

[7] Dee, L. F. (2017). The Power of Course Design to Increase Student Engagement and Learning. Association of American Colleges \& Universities. Retrieved from https://bit.ly/3a9Cv11

[8] Dela Pena, M. M. (2009). E-learning in the Philippines: trends, directions, and challenges. International Journal of on E-learning. 8(4), 1-16. Retrieved from https://bit.ly/37ggON7

[9] Department of Education (2020). The basic education learning continuity plan in the time of COVID-19. Retrieved from https://bit.ly/30DcG6J

[10] Donaldson, S. (2012). Strategies and Applications: Program TheoryDriven Evaluation of Science. Hove, East Sussex BN3 2FA, New York: Routledge. Retrieved from https://bit.ly/37cOUkY

[11] Downes, S. (2010). New technology supporting informal learning. Journal of Emerging Technologies in Web Intelligence, 2(1), 27-33. Retrieved from https://bit.1y/2mStsO0
[12] Funnell, C., \& Rogers, P. J. (2011). Purposeful Program Theory: Effective Use of Theories of Change and Logic Models. San Francisco, California. John Wiley \& Sons. Retrieved from https://bit.ly/2LpUpEw

[13] Han, W.-J., Huang, C.-C., \& Garfinkel, I. (2003). The importance of Family Structure and Family Income on Family's Educational Expenditure and children's College Attendance: Empirical Evidence from Taiwan. Journal of Family Issues, 24(6), 753-786. Retrieved from https://bit.ly/37Dj11O

[14] Juvonen, J., Espinoza, G., \& Knifsend, C. (2012). The Role of Peer Relationships in Student Academic and Extracurricular Engagement. Handbook of Research on Student Engagement, 387-401. Retrieved from https://bit.ly/3qRR5SU

[15] Llego, M. A. (2020). DepEd's readiness for distance learning Professional learning online community of teachers and for teachers. Retrieved from https://bit.ly/30DcG6J

[16] Lynch, M. (2019). 6 elements that hinder the user-friendliness of your online training. The tech advocate. Retrieved from https://bit.ly/33F01AL

[17] Nikitina, A. (2019). Adaptive Learning Technologies For People With ADHD. Educational Technology. Retrieved December 22, 2020, from https://bit.ly/3mJkewe

[18] Rogers, E. M. (2003). Diffusion of innovations. $\left(5^{\text {th }} E d\right.$.). New York: Free Press. Retrieved from https://bit.ly/3mhOFcN

[19] Semuels, A. (2017). Poor Girls are Leaving their Brothers Behind, The Atlantic. Retrieved from https://bit.ly/2KH4w7E

[20] Siemens, G. (2005). Connectivism: A learning theory for the digital age. International Journal of Instructional Technology and Distance Learning, 2(1). Retrieved from https://bit.ly/3h9Eqq0

[21] Parrish, G. (2020). Designing a Course. The Teaching Center. Retrieved from https://bit.ly/30Gw96r

[22] Philippines Statistics Authority (2019). Filipino Families in the Poorest Decile Earn Six Thousand Pesos Monthly, on Average in 2012 (Results from the 2012 Family Income and Expenditure Survey). Retrieved from https://bit.ly/2KHkXRo

[23] Wragg, E.T., Raby, C., Ménard, L., \& Plante, I. (2019). The use of diversified teaching strategies by four university teachers: what contribution to their students' learning motivation?, Teaching in Higher Education, Retrieved from https://bit.ly/3h6F4EO 